Document downloaded from:

http://hdl.handle.net/10251/37755

This paper must be cited as:

Aznar Gimeno, E.; Mondragón Martínez, L.; Ros-Lis, JV.; Sancenón Galarza, F.; Marcos Martínez, MD.; Martínez Mañez, R.; Soto Camino, J.... (2011). Finely Tuned TemperatureControlled Cargo Release Using Paraffin-Capped Mesoporous Silica Nanoparticles. ANGEW CHEM. 123(47):11368-11371. doi:10.1002/ange.201102756.

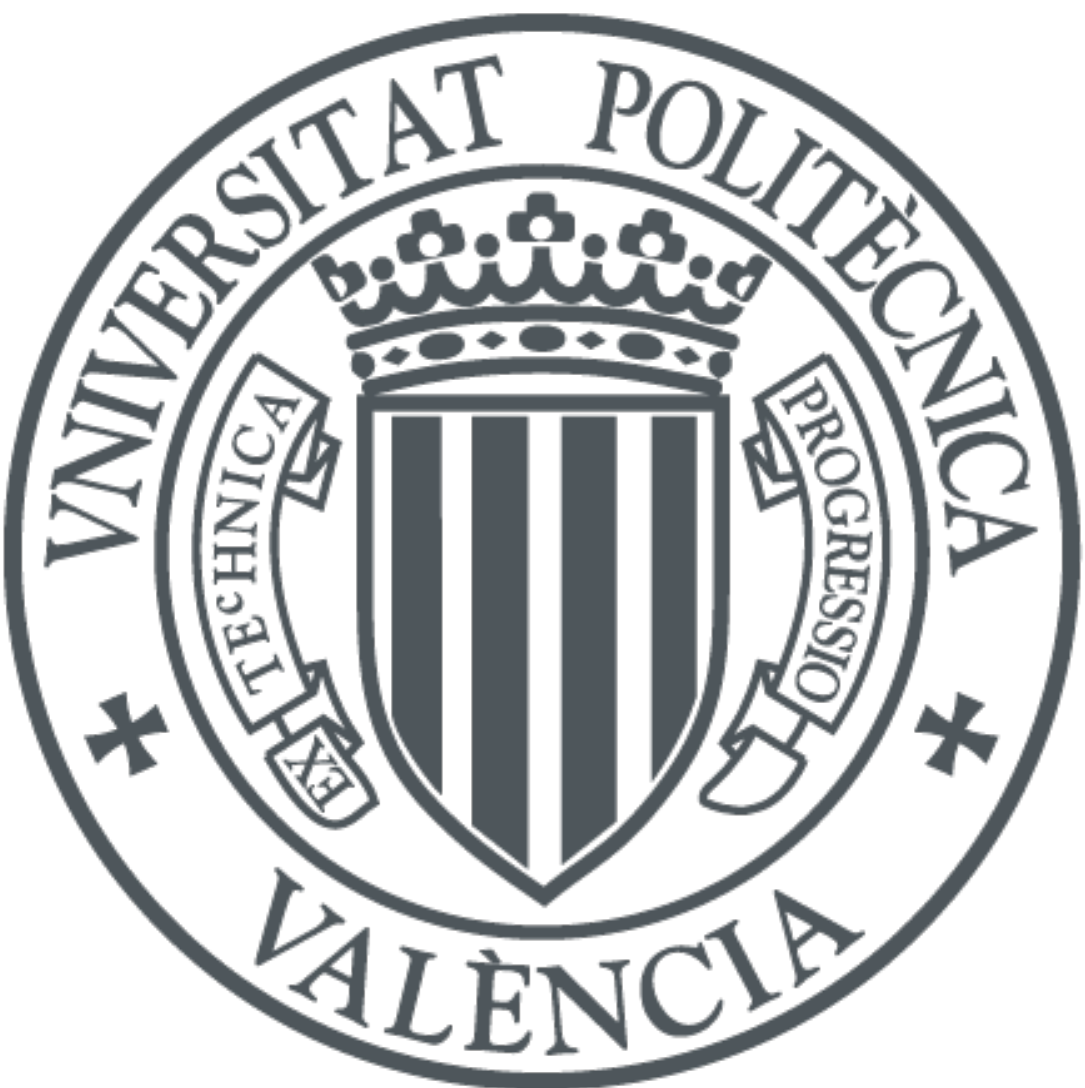

The final publication is available at

http://dx.doi.org/ 10.1002/ange.201102756

Copyright Wiley-VCH Verlag

Additional Information 


\title{
Finely tuned temperature-controlled cargo release using paraffin-capped mesoporous silica nanoparticles
}

\author{
Elena Aznar, Laura Mondragón, José V. Ros-Lis, Félix Sancenón, M. Dolores Marcos, Ramón \\ Martínez-Máñez, * Juan Soto, Enrique Pérez-Payá, Pedro Amorós
}

\begin{abstract}
Stimuli-responsive capped mesoporous materials have demonstrated to be fascinating vehicles for the storage and controlled release of entrapped guests. ${ }^{[1]}$ Chemical triggers as the presence of anions, ${ }^{[2]}$ small redox molecules, ${ }^{[3]}$ antigens, ${ }^{[4]}$ oligonucleotides $^{[5]}$ and enzymes ${ }^{[6]}$ have been used to develop gated materials with controlled release features, but also physical stimuli as light ${ }^{[7]}$ and temperature ${ }^{[8]}$ have attracted the attention thanks to the possibility of remote activation. To date, temperature-controlled release of molecules from pore voids of mesoporous materials has mainly been achieved using the thermosensitive poly( $\mathrm{N}$-isopropyl acrilamide) (PNIPAAm) derivative. ${ }^{[\mathrm{a}-\mathrm{g}]}$ More recently Bein et al. described a molecular valve that releases the entrapped fluorescein upon heating up to the specific melting temperature of double stranded DNA sequences attached to the pore openings of mesoporous nanoparticles. ${ }^{\left[{ }^{[h]}\right]}$ Despite these examples, temperaturecontrolled release of molecules from mesoporous materials is still in
\end{abstract}

[*] Dr. E. Aznar, Dr. L. Mondragón, Dr. J.V. Ros-Lis, Dr. F. Sancenón, Dr. M. D. Marcos, Prof. R. Martínez-Máñez, Dr. J. Soto

Centro de Reconocimiento Molecular y Desarrollo

Tecnológico (IDM). Unidad Mixta Universidad Politécnica de Valencia-Universidad de Valencia, Spain.

Departamento de Química

Universidad Politécnica de Valencia

Camino de Vera s/n, 46022, Valencia, Spain

Fax: (+34) 963879349

E-mail: rmaez@qim.upv.es

CIBER de Bioingeniería, Biomateriales y Nanomedicina (CIBER-BBN)

\section{Prof. P. Amorós}

Institut de Ciència dels Materials (ICMUV), Universitat de Valencia, P.O. Box 2085, E-46071, Valencia, Spain.

Prof. E. Pérez-Payá

Centro de Investigación Príncipe Felipe, Laboratorio de Péptidos y Proteínas, Avda. Autopista al Saler, 16, E-46012 Valencia, Spain

IBV-CSIC, Jaime Roig, 11, E-46010, Valencia, Spain.

[**] Financial support from the Spanish Government (projects MAT2009-14564-C04-01 and SAF2010-15512) and the Generalitat Valenciana (projects PROMETEO/2009/016 and PROMETEO/2010/005) is gratefully acknowledged. L. M. thanks the Generalitat Valenciana for her VALi+d postdoctoral contract. We would like to thank UPV electron microscopy and CIPF confocal microscopy services for technical support.

Supporting information for this article is available on the WWW under http://www.angewandte.org or from the author. its infancy and for instance there are not reported examples where the temperature release could be easily customized depending on target requirements.

Taking into account these concepts and being aware of the promising features of silica mesoporous supports (SMPS) as containers, ${ }^{[9]}$ we focused our attention on the development of new tailor-made temperature-responsive gated mesoporous materials.
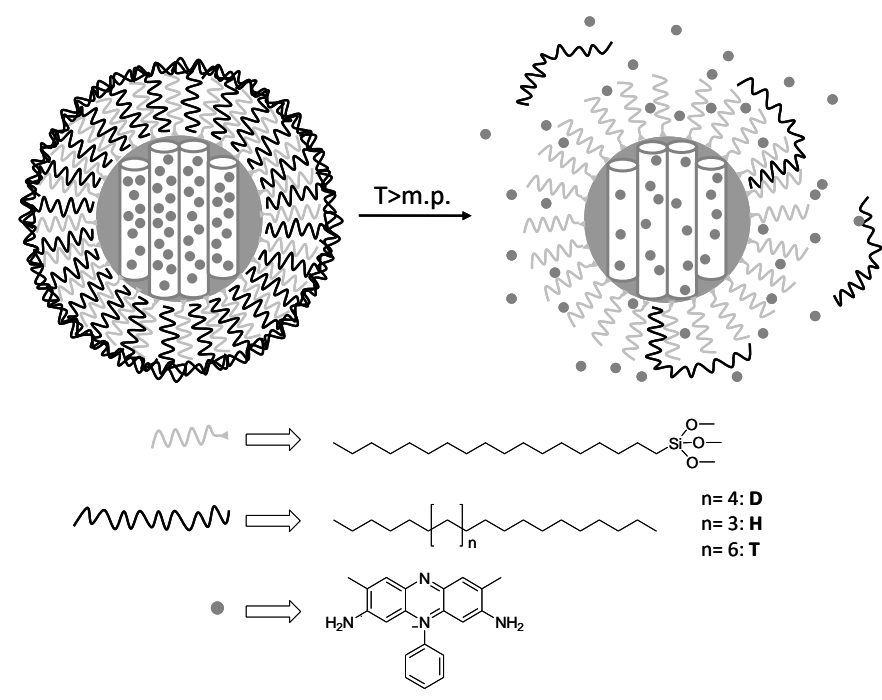

Scheme 1. Representation of the gated material $\mathbf{S} 1$ functionalized with octadecyltrimethoxysilane and capped with paraffin. The delivery of the entrapped guest (Safranine O) is triggered when temperature rises above paraffin melting point.

The expected performance of the new gated material, depicted in Scheme 1, is based on the use of paraffins as capping molecules that can be melted at a fixed temperature. In this work silica mesoporous nanoparticles (ca. 100-150 nm) have been selected as inorganic scaffold. The MCM-41 support was loaded with a suitable guest (Safranine O) and the external surface was functionalized with octadecyltrimethoxysilane (solid S1). These alkyl chains are not able to close the pores but are suitable to interact with paraffins (vide infra) via London forces setting up a hydrophobic layer that could block the pores inhibiting guest release. An increase of the temperature above paraffin melting point would result in the paraffin melting and the subsequent uncapping of the pores.

S1 was characterized using standard procedures (see Supporting Information). X-ray diffraction pattern of S1 (Figure 1) shows the mesoporous characteristic (100) diffraction peak indicating that the loading process with the dye and the further functionalization with octadecyltrimethoxysilane have not modified the structure of the mesoporous scaffolding. Moreover, $0.44 \mathrm{mmol} \mathrm{g}^{-1} \mathrm{SiO}_{2}$ of dye and $0.76 \mathrm{mmol} \mathrm{g}^{-1} \mathrm{SiO}_{2}$ of octadecyl on solid $\mathbf{S 1}$ were determined by elemental analysis and thermogravimetric studies. 
For the preparation of gated material S1-D, the paraffin docosane D was selected (melting point $42^{\circ} \mathrm{C}$ ). $150 \mathrm{mg}$ of $\mathbf{S 1}$ were dispersed in $120 \mathrm{~mL}$ of hexane sonicating during 30 minutes. Then, $1.5 \mathrm{~g}$ of $\mathbf{D}$ were added and the suspension (see Supporting Information for details). The final S1-D solid was isolated by centrifugation and dried under vacuum. This synthetic procedure assures that the final hybrid solid contains Safranine $O$ inside of mesopores and the corresponding paraffin as coating surrounding the nanoparticle. The contents in solid S1-D of Safranine O and paraffin D (determined via thermogravimetric analysis) were 0.42 and $0.15 \mathrm{mmol} \mathrm{g}^{-1} \mathrm{SiO}_{2}$, respectively. Figure 1 shows TEM images of calcined MCM-41 and S1-D. For the latter the paraffin coating can be clearly observed.

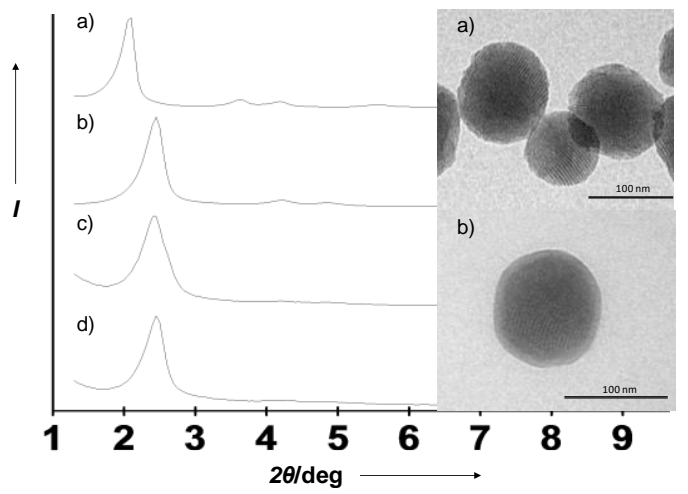

Figure 1. Left: powder X-ray diffraction patterns of (a) MCM-41 as synthesized (b) calcined MCM-41 (c) S1 and (d) S1-D. Right: TEM images of (a) calcined MCM-41 and (b) S1-D showing the typical porosity of the MCM- 41 mesoporous matrix and the parrafin coating.

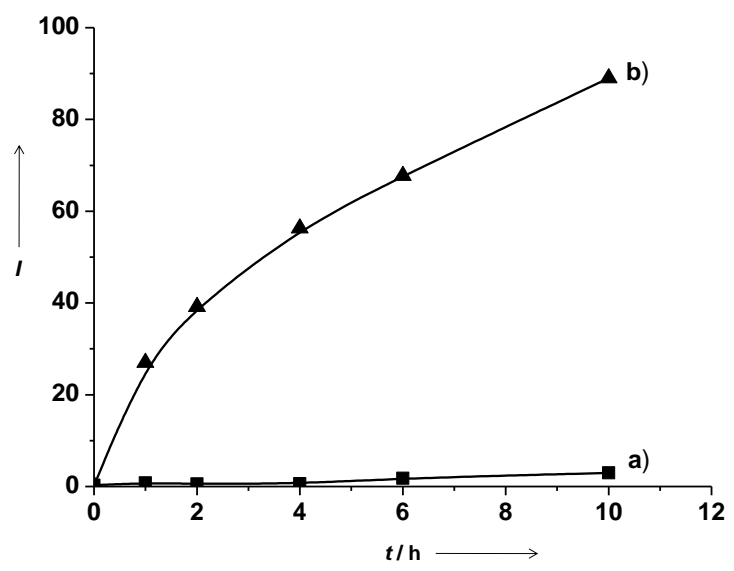

Figure 2. Release of Safranine $\mathrm{O}$ from solid S1-D at $40{ }^{\circ} \mathrm{C}$ (curve a) and $44 \stackrel{\circ}{\circ}$ (curve b).

In order to investigate the gating properties of the solid, S1-D was suspended in a thermostatized vase containing deionized water (see Supporting Information). The suspension was stirred at $40{ }^{\circ} \mathrm{C}$. The same procedure was repeated with S1-D adjusting the temperature at $44{ }^{\circ} \mathrm{C}$. The fluorescence emission at $585 \mathrm{~nm}\left(\lambda_{\mathrm{ex}}=520 \mathrm{~nm}\right)$ of the released Safranine $\mathrm{O}$ at the two temperatures as a function of time is displayed in Figure 2. At $40^{\circ} \mathrm{C}$ solid S1-D was tightly capped and showed a negligible release of the dye (curve a). In contrast, when temperature was adjusted at $44{ }^{\circ} \mathrm{C}$, the entrapped Safranine O probe escaped from the pore voids due to a temperature-dependent uncapping event (curve b). Quantitatively, the release at $44^{\circ} \mathrm{C}$ was 30 -fold higher than at $40^{\circ} \mathrm{C}$ in 1 hour and the difference exceeded 100 -fold in 4 hours. Further experiments showed that a $36 \%$ of total entrapped dye was released after 10 hours at $44^{\circ} \mathrm{C}$.

In a second step delivery from $\mathbf{S 1}$ was also studied as a function of the melting point of the temperature-responsive layer. For these experiments the paraffins heneicosane $\mathbf{H}$ (melting point $39^{\circ} \mathrm{C}$ ) and tetracosane $\mathbf{T}$ (melting point $49{ }^{\circ} \mathrm{C}$ ) were selected. The corresponding solids S1-H and S1-T were prepared following the same procedure as that used for S1-D. The new solids showed similar Safranine O release profiles to S1-D (see Figures SI-1 and SI-3). Furthermore, the temperature-dependent performance of the hybrid materials was evaluated by suspending the corresponding solid in deionized water at a given temperature for 2 hours (Figure 3). After this time, suspensions were filtered and the release of Safranine O determined.

The results, depicted in Figure 3, confirmed how an appropriate paraffin selection allows a fine tune triggering event customization. In fact, the temperature needed to release 50\% (TR50) of the entrapped probe were $39^{\circ} \mathrm{C}, 42^{\circ} \mathrm{C}$ and $50^{\circ} \mathrm{C}$ for solids S1-H, S1-D and S1-T, respectively. It is remarkable that solid S1-T showed a negligible release below $49^{\circ} \mathrm{C}$ although at such high temperatures diffusion processes could have some relevance.

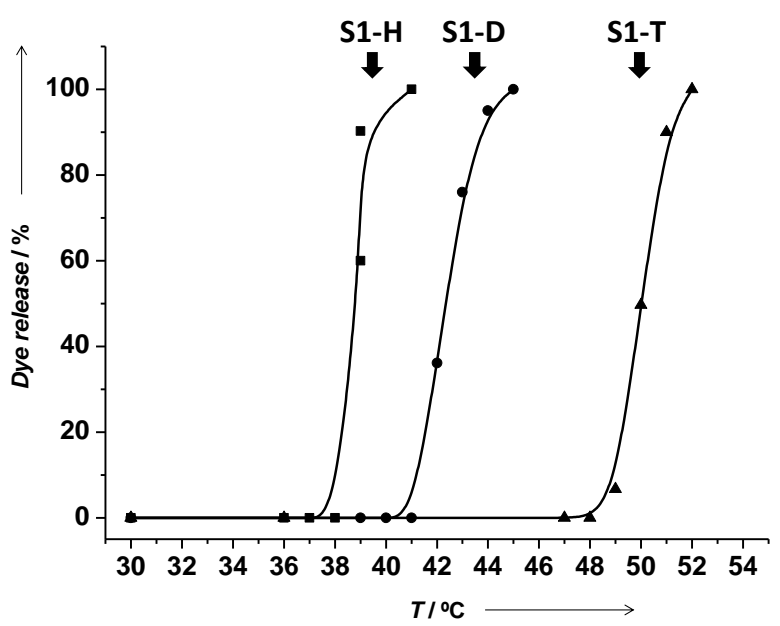

Figure 3. Release profile of solids S1-H, S1-D and S1-T at different temperatures. Release data were normalized to the maximum delivery obtained for each solid.

These hybrid nanoparticles can have biological applications as nanodevices for intracellular temperature-controlled release of molecules. To study this possibility, solid S1-H (TR50, $39^{\circ} \mathrm{C}$ ) was initially evaluated in HeLa cells (see Supporting Information). Briefly, cells were incubated in duplicate in the presence of S1-H for one hour; excess of solid S1-H was removed and cells were placed in fresh medium for three additional hours to allow a complete internalization of the nanoparticles. Subsequently, one cellular sample set was incubated for three hours at $42{ }^{\circ} \mathrm{C}$ in order to induce melting of the solid S1-H coverage, while the second was kept at $37{ }^{\circ} \mathrm{C}$. Twelve hours later, the release of Safranine $\mathrm{O}$ was analysed by confocal microscopy. Figure 4 shows representative images of HeLa cells treated with solid S1-H at $37^{\circ} \mathrm{C}$ (4a) and at 42 ${ }^{\circ} \mathrm{C}$ (4b). The Safranine O probe (in red colour) was found spread in the cell cytoplasm in cells incubated at $42{ }^{\circ} \mathrm{C}$, but not in those cells 
incubated at $37^{\circ} \mathrm{C}$ due to a temperature-dependent uncapping of the internalized solid $\mathbf{S 1 - H}$.
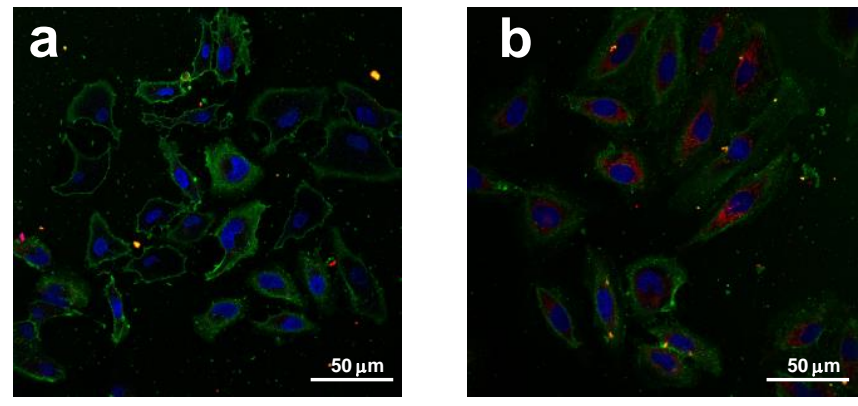

Figure 4. Confocal microscopy images corresponding to HeLa cells treated with solid S1-H $(200 \mu \mathrm{g} / \mathrm{mL})$ and incubated at $37^{\circ} \mathrm{C}$ (a) and $42{ }^{\circ} \mathrm{C}$ (b). The cellular internalization of $\mathbf{S 1 - H}$ was followed by Safranine $O$ associated fluorescence (red) in the presence of DNA marker Hoechst 33342 (blue) and the plasma membrane marker WGA Alexa Fluor 647 (green)

Moving a step forward in our research, our next purpose was to demonstrate the possible application of these nanoparticles as temperature-dependent drug-carriers for on-command delivery inside cells. In this case, S1-H was loaded with the chemotherapeutic agent doxorubicin (DOX). The release profile and performance of S1-H-DOX were similar to solids loaded with Safranine O (see Figure SI-4). S1-H-DOX induced cell death that can be traced at the early events by an exposure of phosphatidylserine to the external face of the cellular membrane (Annexin V - Ann V - is an appropriate marker - see Supporting Information). Late events of cell death are characterized by membrane cell permeabilization that allows the incorporation to the cell of nuclear markers such as DAPI. HeLa cells were treated as described before in the presence of this new nanoparticle S1-HDOX. At $37{ }^{\circ} \mathrm{C}$ both, control and S1-H-DOX treated cells showed characteristics of healthy cells as determined by flow cytometry (negative for both Ann V and DAPI - Figure 5). However, confocal images of cells treated with S1-H-DOX and incubated at $42{ }^{\circ} \mathrm{C}$, showed morphological features such as cell detachment, reduction of cellular volume and cellular shrinkage. Moreover, at $42{ }^{\circ} \mathrm{C}, 60 \%$ of S1-H-DOX-treated, but not control, cells showed characteristics of DOX-induced cell death and the analysis suggested that close to $40 \%$ of cells were developing the cell death program (Ann V positive, DAPI negative) while close to $20 \%$ of the cells (DAPI positive) were at the late stages of such program. These results confirmed the temperature-dependent release of DOX in cells.

In short, we reported herein a new family of temperatureresponsive hybrid nanoscopic solids that are uncapped at a given temperature. The materials were prepared using MCM-41 supports functionalized with octadecyltrimethoxysilane and the further addition of paraffins that are able to form a hydrophobic layer that inhibited cargo release. An increase of the temperature above paraffin melting point results in the release of the entrapped guest. The finely tuned tailor-made temperature triggered delivery achieved in these capped systems and the possibility to select a wide range of paraffins with specific melting points in a wide range of temperatures make these solids suitable for applications that demand zero release before stimuli implementation and render them important in delivery applications triggered by selected global or local temperature changes.

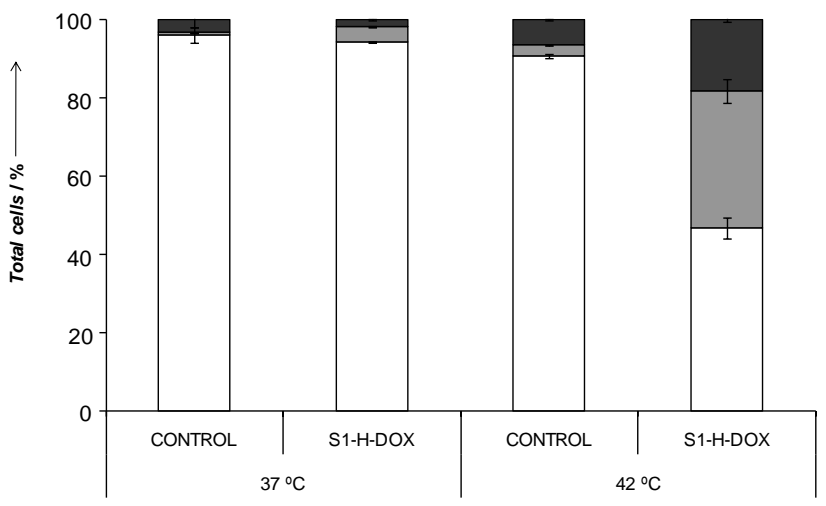

Figure 5. Cell viability studies. HeLa cells were treated or not with S1H-DOX as described for S1-H and incubated at $37{ }^{\circ} \mathrm{C}$ or $42{ }^{\circ} \mathrm{C}$. Then, DAPI and Ann $V$ stainings were performed to determine cell viability and cell death induction, respectively. Percentage of dead cells (black), cells undergoing cell death (grey) and healthy cells (white) are depicted after 18 hours of treatment. Two independent experiments were performed. Data are reported as (mean $\pm \mathrm{SE}$ ).

Received: ((will be filled in by the editorial staff)) Published online on ((will be filled in by the editorial staff))

Keywords: molecular gates - mesoporous nanoparticles - paraffin . temperature $\cdot$ controlled release

[1] a) A. B. Descalzo, R. Martínez-Máñez, F. Sancenón, K. Hoffmann, K. Rurack, Angew. Chem. 2006, 118, 6068-6093; Angew. Chem. Int. Ed. 2006, 45, 5924-5948; b) B. G. Trewyn, I. I. Slowing, S. Giri, H. T. Chen, V. S. -Y. Lin, Acc. Chem. Res. 2007, 40, 846-853; c) I.I. Slowing, J. L. Vivero-Escoto, C. W. Wu, V. S. -Y. Lin, Adv. Drug Deliv. Rev. 2008, 60, 1278-1288; d) E. Aznar, R. Martínez-Máñez, F. Sancenón, Expert Opin. Drug Deliv. 2009, 6, 643-655; e) K. Cotí, M. E. Belowich, M. Liong, M. W. Ambrogio, Y. A. Lau, H. A. Khatib, J. I. Zink, N. M. Khashab, J. F. Stoddart, Nanoscale, 2009, 1, 16-39.

[2] a) R. Casasús, E. Climent, M. D. Marcos, R. Martínez-Máñez, F. Sancenón, J. Soto, P. Amorós, J. Cano, E. Ruiz, J. Am. Chem. Soc. 2008, 130, 1903-1917; b) C. Coll, R. Casasús, E. Aznar, M. D. Marcos, R. Martínez-Máñez, F. Sancenón, J. Soto, P. Amorós, Chem. Commun. 2007, 1957-1959; c) R. Casasús, E. Aznar, M. D. Marcos, R. Martínez-Máñez, F. Sancenón, J. Soto, P. Amorós, Angew. Chem. 2006, 118, 6813-6816; Angew. Chem. Int. Ed. 2006, 45, 6661-6664; d) E. Aznar, C. Coll, M. D. Marcos, R. Martínez-Máñez, F. Sancenón, J. Soto, P. Amorós, J. Cano, E. Ruiz, Chem. Eur. J. 2009, 15, 6877-6888. [3] a) F. Torney, B. G. Trewyn, V. S. -Y. Lin, K. Wang, Nat. Nanotechnol. 2007, 2, 295-300; b) D. R. Radu, C.-Y Lai, K. Jeftinija, E. W. Rowe, S. Jeftinija, V. S. -Y. Lin, J. Am. Chem. Soc. 2004, 126, 13216-13217; c) S. Giri, B. G. Trewyn, M. P. Stellmaker, V. S. -Y. Lin, Angew. Chem. 2005, 117, 5166-5172; Angew. Chem. Int. Ed. 2005, 44, 5038-5044; d) I. I. Slowing, B. G. Trewyn, V. S. -Y. Lin, J. Am. Chem. Soc. 2007, 129, 8845-8849; e) I. I. Slowing, B. G. Trewyn, S. Giri, V. S. -Y. Lin, Adv. Funct. Mater. 2007, 17, 1225-1236; f) R. Mortera, J. Vivero-Escoto, I. I. Slowing, E. Garrone, B. Onida, V. S. Y. Lin, Chem. Commun. 2009, 3219-3221; g) Y. Zhao, B. G. Trewyn, I. I. Slowing, V. S. -Y. Lin, J. Am. Chem. Soc. 2009, 131, 8398-8400; h) R. Hernandez, H. -R. Tseng, J. W. Wong, J. F. Stoddart, J. I. Zink, J. Am. Chem. Soc. 2004, 126, 3370-3371; i) T. D. Nguyen, H. -R. Tseng, P. C. Celeste, A. H. Flood, Y. Liu, J. F. Stoddart, J. I. Zink, Proc. Natl. Acad. Sci. USA 2005, 102, 10029-10034; j) T. D. Nguyen, Y. Liu, S. Saha, K. C. -F Leung, J. F. Stoddart, J. I. Zink, J. Am. Chem. 
Soc. 2007, 129, 626-634; k) T. D. Nguyen, K. C. -F. Leung, M. Liong, Y. Liu, J. F. Stoddart, J. I. Zink, Adv. Funct. Mater. 2007, 17, 21012110 ; 1) M. Fujiwara, S. Terashima, Y. Endo, K. Shiokawa, H. Ohue Chem. Commun. 2006, 4635-4637; m) R. Liu, X. Zhao, T. Wu, P. Feng, J. Am. Chem. Soc. 2008, 130, 14418-14419.

[4] E. Climent, A. Bernardos, R. Martínez-Máñez, A. Maquieira, M. D. Marcos, N. Pastor-Navarro, R. Puchades, F. Sancenón, J. Soto, P. Amorós, J. Am. Chem. Soc. 2009, 131, 14075-14080.

[5] E. Climent, R. Martínez-Máñez, F. Sancenón, M. D. Marcos, J. Soto, A. Maquieira, P. Amorós, Angew. Chem. Int. Ed. 2010, 49, 7281-7283.

[6] a) K. Patel, S. Angelos, W. R. Dichtel, A. Coskun, Y. -W. Yang, J. I. Zink, J. F. Stoddart, J. Am. Chem. Soc. 2008, 130, 2382-2383; b) A. Schlossbauer, J. Kecht, T. Bein, Angew. Chem. 2009, 121, 3138-3141; Angew. Chem. Int. Ed. 2009, 48, 3092-3095; c) A. Bernardos, E Aznar, M. D. Marcos, R. Martínez-Máñez, F. Sancenón, J. Soto, J. M. Barat, P. Amorós, Angew. Chem. 2009, 121, 5998-6001; Angew. Chem. Int. Ed. 2009, 48, $5884-5887$; d) C. Park, H. Kim, S. Kim, C. Kim, J. Am. Chem. Soc. 2009, 131, 16614-16615; e) A. Bernardos, L. Mondragón, E. Aznar, M. D. Marcos, R. Martínez-Máñez, F. Sancenón, J. Soto, J. M. Barat, E. Pérez-Payá, C. Guillem, P. Amorós, ACS Nano 2010, 4, 6353.

[7] a) N. K. Mal, M. Fujiwara, Y. Tanaka, Nature 2003, 421, 350-353; b) N. K. Mal, M. Fujiwara, Y. Tanaka, T. Taguchi, M. Matsukata, Chem. Mater. 2003, 15, 3385-3394; c) Y. Zhu, M. Fujiwara, Angew. Chem. Int. Ed. 2007, 46, 2241-2244; d) N. G. Liu, Z. Chen, D. R. Dunphy, Y. -B. Jiang, R. A. Assink, C. J. Brinker, Angew. Chem. Int. Ed. 2003, 42 , 1731-1734; e) N. G. Liu, D. R. Dunphy, P. Atanassov, S. D. Bunge, Z. Chen, G. P. Lopez, T. J. Boyle, C. J. Brinker, Nano Lett. 2004, 4, 551554; f) S. Angelos, E. Choi, F. Vögtle, L. De Cola, J. I. Zink, J. Phys. Chem. C 2007, 111, 6589-6592; g) J. Liu, E. Choi, F. Tamanoi, J. I Zink, Small 2008, 4, 421-426; h) J. L. Vivero-Escoto, I. I. Slowing, C. -W. Wu, V. S. -Y. Lin, J. Am. Chem. Soc. 2009, 131, 3462-3463; i) E.
Aznar, R. Casasús, B. García-Acosta, M. D. Marcos, R. MartínezMáñez, F. Sancenón, J. Soto, P. Amorós, Adv. Mater. 2007, 19, 22282231; j) E. Aznar, M.D. Marcos, R. Martínez-Máñez, F. Sancenón, J. Soto, P. Amorós, C. Guillem, J. Am. Chem. Soc. 2009, 131, $6833-$ 6843.

[8] a) Q. Fu, G. V. R. Rao, L. K. Ista, Y. Wu, B. P. Andrzejewski, L. A. Sklar, T. L. Ward, G. P. López, Adv. Mater. 2003, 15, 1262-1266; b) Q. Fu, G. V. R. Rao, T. L. Ward, Y. Lu, G. P. López, Langmuir 2007, 23, 170-174; c) Z. Y. Zhou, S. M. Zhu, D. Zhang, J. Mater. Chem. 2007, 17, 2428-2433; d) S. Zhu, Z. Zhou, D. Zang, C. Jin, Z. Li, Micropor. Mesopor. Mater. 2007, 106, 56-61; e) Y. Zhu, S. Kaskel, T. Ikoma, N. Haganata, Micropor. Mesopor. Mater. 2009, 123, 107-112; f) Y. -Z. You, K. K. Kalebaila, S. L. Brock, D. Oupicky, Chem. Mater. 2008, 20, 3354-3359; g) C. Liu, J. Guo, W. Yang, J. Hu C. Wang, S. Fu, J. Mater. Chem. 2009, 19, 4764-4770; h) A. Schossbauer, S. Warncke, P. M. E. Gramlich, J. Kecht, A. Manetto, T. Carell, T. Bein, Angew. Chem. Int. Ed. 2010, 49, 4734-4737.

[9] a) J. S. Beck, J. C. Vartuli, W. J. Roth, M. E. Leonowicz, C. T. Kresge, K. D. Schmitt, C. T. -W. Chu, D. H. Olson, E. W. Sheppard, S. B. McCullen, J. B. Higgins, J. L. Schlenker, J. Am. Chem. Soc. 1992, 114 10834-10843; b) A. P. Wright, M. E. Davis, Chem. Rev. 2002, 102, 3589-3614; c) G. Kickelbick, Angew. Chem. 2004, 116, 3164-3166; Angew. Chem. Int. Ed. 2004, 43, 3102-3104; d) A. Stein, Adv. Mater. 2003, 15, 763-775. 


\section{Table of Contents}

\section{Molecular gates}

E. Aznar, L. Mondragón, J.V. Ros-Lis, F. Sancenón, M.D. Marcos, R. MartínezMáñez, ${ }^{\star} J$. Soto, E. Pérez-Payá, P. Amorós Page - Page

Intracellular-temperature

controlled release via paraffin-capped mesoporous silica nanoparticles

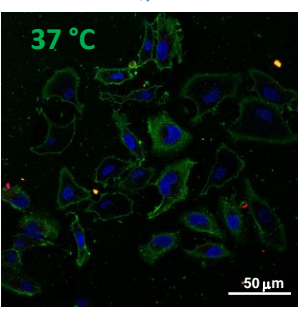

We reported herein a new family of finely tuned tailor-made temperatureresponsive hybrid nanoscopic

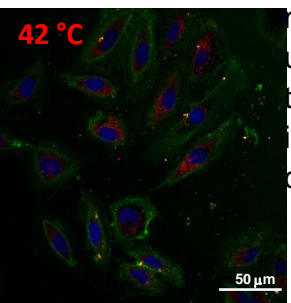
mesoporous materials that are uncapped at a given temperature and heir potential application as vehicles for ntracellular on-command delivery of chemotherapeutics. 